\title{
Dubowitz syndrome
}

INSERM

\section{Source}

INSERM. (1999). Orphanet: an online rare disease and orphan drug data base. Dubowitz syndrome. ORPHA:235

Dubowitz syndrome (DS) is a rare multiple cong enital syndrome characterized primarly by growth retardation, microcephaly, distinctive facial dysmorphism, cutaneous eczema, a mild to severe intellectual deficit and genital abnormalities. 